(c) Group of authors, 2016

UDC 61: [616.71-007.15+61.575]

DOI - http://dx.doi.org/10.14300/mnnc.2016.11029

ISSN - 2073-8137

\title{
METATROPIC DYSPLASIA: CLINICAL AND MOLECULAR DIAGNOSTICS, GENETIC COUNSELING
}

Timkovskaya E. E. ${ }^{1}$, Makaov A. Kh.-M. ${ }^{2}$, Mikhailova L. K. ${ }^{3}$, Vasilyeva T. A. ${ }^{1}$, Marakhonov A. V. ${ }^{1}$, Galkina V. A. ${ }^{1}$, Kutsev S. I. ${ }^{1,4}$, Zinchenko R. A. ${ }^{1,4}$

${ }^{1}$ Research Centre for Medical Genetics, Moscow, Russian Federation

2 Habez Central District Hospital, Karachai-Cherkess Republic, Russian Federation

${ }^{3}$ Central Research Institute of Traumatology and Orthopedics by N. N. Priorova, Moscow, Russian Federation

${ }^{4}$ Pirogov Russian National Research Medical University, Moscow, Russian Federation

\section{МЕТАТРОПНАЯ АИСПААЗИЯ: КАИНИЧЕСКАЯ И МОАЕКУАЯРНАЯ АИАГНОСТИКА, МЕАИКО-ГЕНЕТИЧЕСКОЕ КОНСУАЬТИРОВАНИЕ}

Е. Е. Тимковская ${ }^{1}$, А. Х.-М. Макаов², А. К. Михай^ова', Т. А. Васильева',

А. В. Марахонов ${ }^{1}$, В. А. Галкина' ${ }^{1}$, С. И. Куцев ${ }^{1,4}$, Р. А. Зинченко ${ }^{1,4}$

${ }^{1}$ Медико-генетический научный центр, Москва, Российская ФеАерация

2 Хабезская центральная районная больница,

Карачаево-Черкесская Республика, Российская Фелерация

3 Центральный научно-исслеАовательский институт травматологии и ортопеАии имени Н. Н. Приорова, Москва, Российская ФеАерация

4 Российский национаАьный исслеАовательский МеАицинский Университет имени Н. И. Пирогова, Москва, Российская ФеАерация

Metatropic dysplasia (MTD; OMIM \#156530) is a rare spondyloepimetaphyseal dysplasia with autosomal dominant inheritance. Here we present the results of the clinical, radiological and molecular genetic diagnosis of MTD in a circassian girl with novel de novo p.Pro82Leu (NG 017090.1:g.23856C >T, c.245C>T) mutation in exon 1 of the TRPV4 gene. Considering gonadal mosaicism prenatal diagnosis in MTD families for the next pregnancies is recommended.

Key words: genetic epidemiology, metatropic dysplasia, TRPV4 gene, mutation de novo

Метатропная дисплазия (МТД; ОМІМ \#156530) является редкой спондилоэпиметафизарной дисплазией с аутосомно-доминантным типом наследования. В статье представлены результаты клинической, рентгенологической и молекулярно-генетической диагностики МТД у черкесской девочки. Выявлена ранее неописанная мутация de novo p.Pro82Leu (NG_017090.1: g.23856C>T, c.245C>T) в экзоне 1 гена TRPV4. Учитывая вероятность повторного рождения больного ребенка из-за возможности гонадного мозаицизма, всем семьям с МТД рекомендована пренатальная диагностика.

Ключевые слова: генетическая эпидемиология, метатропная дисплазия, ген TRPV4, мутация de novo

M etatropic dysplasia (OMIM \#156530, MTD) is a rare skeletal disorder, which was initially described as a separate entity in 1966 [4]. The word "metatropic" is derived from the Greek "metatropos" which means dwarfism "with change". The prevalence is unknown, it is supposed to be $<1 / 1000000$. Approximately 81 cases had been reported in the literature up to 2014 [5].

Characteristic abnormalities include severe dwarfism (final adult height sranged from 107 to 135 $\mathrm{cm}$ ), progressive kyphoscoliosis, distortion and bowing of the extremities contractures of the large joints and craniofacial dysmorphy - in frontal bossing and midface hypoplasia [2, 4]. Kyphoscoliosis can lead to thorax deformities and to a decrease in pulmonary function and respiratory distress that can be fatal. MTD radiologically characterized by marked platyspondyly, a halberd pelvis/proximal femurs, short limbs, a narrow thorax with short ribs, and metaphyseal flaring resulting in the so called «dumbbell» appearance of the long bones [2].

Until 2009 there were two MTD nosologic forms with an autosomal recessive (OMIM 250600) and autosomal dominant inheritance (OMIM \#156530) [6]. After 
responsible gene TRPV4 mapping (locus 12q24.11), MTD is proposed to represent a single gene dominant condition and rare sib recurrence can be accounted due to gonadal mosaicism $[3,4,7]$.

TRPV4 gene encodes for the calcium-permeable cation channel with nonselective permeability to calcium; it is expressed and involved in a number of cellular and physiological processes through responses to different stimuli. The participation of TRPV4 in osmo- and mechanotransduction is relevant to several important functions, including cellular and systemic volume homeostasis, arterial dilation and nociception [5]. Over 50 mutations in TRPV4 gene have been described.

While most pathogenic mutations tested so far result in activation of the calcium channel in vitro, the mechanisms through which TRPV4 activation results in skeletal dysplasia and/or peripheral neuropathy remain unclear and the genotype-phenotype correlations in this group of disorders remains puzzled [2]. Pathogenic changes in this gene are thought to cause an increase in calcium in the chondrocytes and consequently disrupted endochondral ossification and the clinical manifestations of MTD [5].

The phenotypic spectrum of MTD is variable from severe cases being lethal in utero, or shortly after birth, to others having only milder skeletal changes. MTD forms were classified according to their severity into four types by Kozlowski et al. [1]. Type 1 is perinatally lethal and also described as «lethal hyperplastic metatropic dysplasia». Type 2 is perinatally lethal or lethal in early childhood, it is known as "lethal metatropic dysplasia» or «hyperchondrogenesis». Type 3 is classic surviving, severe «metatropic dysplasia». Type 4 includes various milder surviving types. However clinical and radiologic findings show considerable overlapping between socalled mild, classic, and lethal forms of MTD and cannot be reliably separated $[2,4]$.

Material and Methods. The study was conducted as part of the extensive genetic and epidemiological studies of the peoples of the European part of Russia, carried out by genetic epidemiology laboratory of the Research Centre for Medical Genetics, (Moscow, Russian Federation) for 30 years. Examination of the patients was carried out in expedition conditions. Confirmatory clinical diagnosis was carried out on the basis of family history, physician examination and $\mathrm{X}$-ray data.

Genomic DNA was extracted by standard procedures from peripheral blood of the patient, her family members and healthy individuals after informed consent at the Laboratory of Genetic Epidemiology of the Research Centre for Medical Genetics, Moscow, Russian Federation. The study was approved by its Internal Review Board (IRB). The exon sequences of TRPV4 and their flanking intronic sequences (The GenBank reference sequence: NM 021625.4) were amplified by PCR from genomic DNA.

The polymerase chain reaction (PCR) mixtures contained $50 \mathrm{pg}$ of the template, $1 \mathrm{nM}$ each of the forward and reverse primers, $2.5 \mathrm{mM} \mathrm{MgCl}_{2}, 0.2 \mathrm{mM}$ dNTP mix, 0.5 units of Taq DNA polymerase, and $1 \times$ Taq buffer in a total volume of $10 \mathrm{ml}$. All samples were denatured for 1 min at $94^{\circ} \mathrm{C}$, followed by 32 cycles of denaturation at $94^{\circ} \mathrm{C}$ for 10 seconds, annealing at $60^{\circ} \mathrm{C}$ for 10 seconds, and extension at $72^{\circ} \mathrm{C}$ for 30 seconds in a Tercyc thermocycler (DNA-Technology, Moscow, Russia).
The whole gene TRPV4 sequencing is performed. Oligonucleotides were synthesized by Evrogen Inc., Moscow, Russian Federation.

Bidirectional sequencing of PCR fragments was performed with BigDye Terminator v1.1 Cycle Sequencing Kit on the 3130xI Genetic Analyzer (Applied Biosystems, Foster City, CA). The frequency of identified allele in general population was established based on the Database of Single Nucleotide Variants (dbSNP, http://www.ncbi.nlm.nih.gov/ snp/) and the ExAC browser (http://exac.broadinstitute. org/). The predicted functional effect of the missense variant was determined through PolyPhen, MutationTaster, MutationAssessor. A test system was developed for the screening of detected mutation in 50 healthy Circassians. Forward primer 5'- GACTCCAGCAGATCGCTG-3' with one nucleotide mismatch forms a restriction site for Ddel endonuclease in the mutant allele (reverse primer: 5'GAGGCTTTTCCTCTCTCCTC-3').

Results and Discussion. A Circassian family with MTD was revealed in the course of hereditary diseases study in Khabezsky District of Karachaevo - Cherkessia Republic (Nothern Caucasus Region, Russian Federation).

For the first time 1,5-year-old girl was referred with MTD at the Turner Scientific Research Institute for Children's Orthopedics in St Petersburg in 2014. The diagnosis of MTD was confirmed during clinical and radiography examination at the Central Research Institute of Traumatology and Orthopaedics of N.N. Priorov. At the age of two the child died from pneumonia.

The proband was the first child of healthy nonconsanguineous parents after an unremarkable pregnancy at term. Mother's age at time of the child birth was 21 and father's 27 years old. There was no family history of a skeletal dysplasia.

By the clinical examination time progressive kyphoscoliosis, distortion and bowing of the limbs, muscle hypotonia, movement constriction in large joint and deformed narrow chest were diagnosed (Fig. 1). Face dismorphisms included frontal bossing and midface hypoplasia.
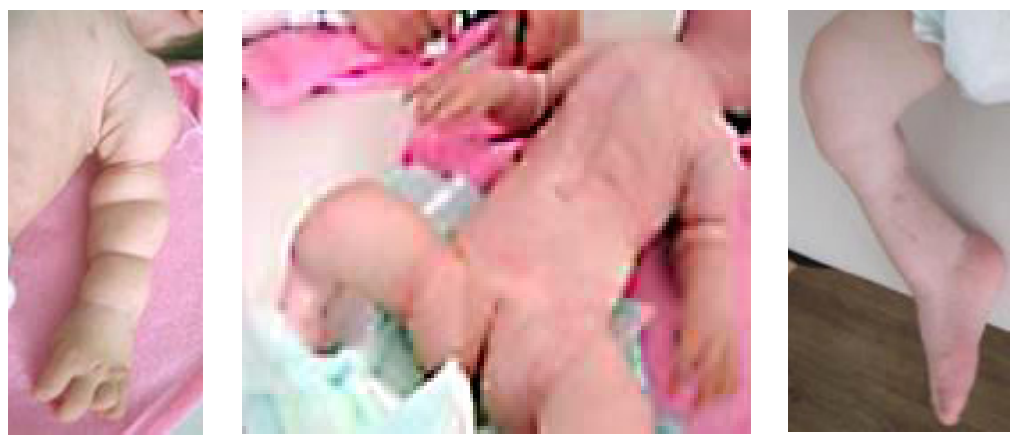

Fig. 1. The MTD affected girl at the age of 1 year and 9 month

Radiology examination showed: kyphoscoliosis; decreased bone density; marked platyspondyly; horizontally elongated thoracic vertebrae, squared-off lumbal vertebrae; shorten and tortuous claviculars; deformed, laterally impacted thorax, hypoplastic in its upper segments; flattened and enlarged in their anterior parts ribs; halberd shaped pelvis, a constriction between ilium corpus and ala; bowing of the long bones; shorten and tortuous femoral, tibia and fibula bones; enlarged femoral joints in the shape of the dumbbell; bilateral femur neck varus deformity; loose femoral head tissue; flattened knee joint epiphyses; equinus and porous calcaneus (Fig. 2). 

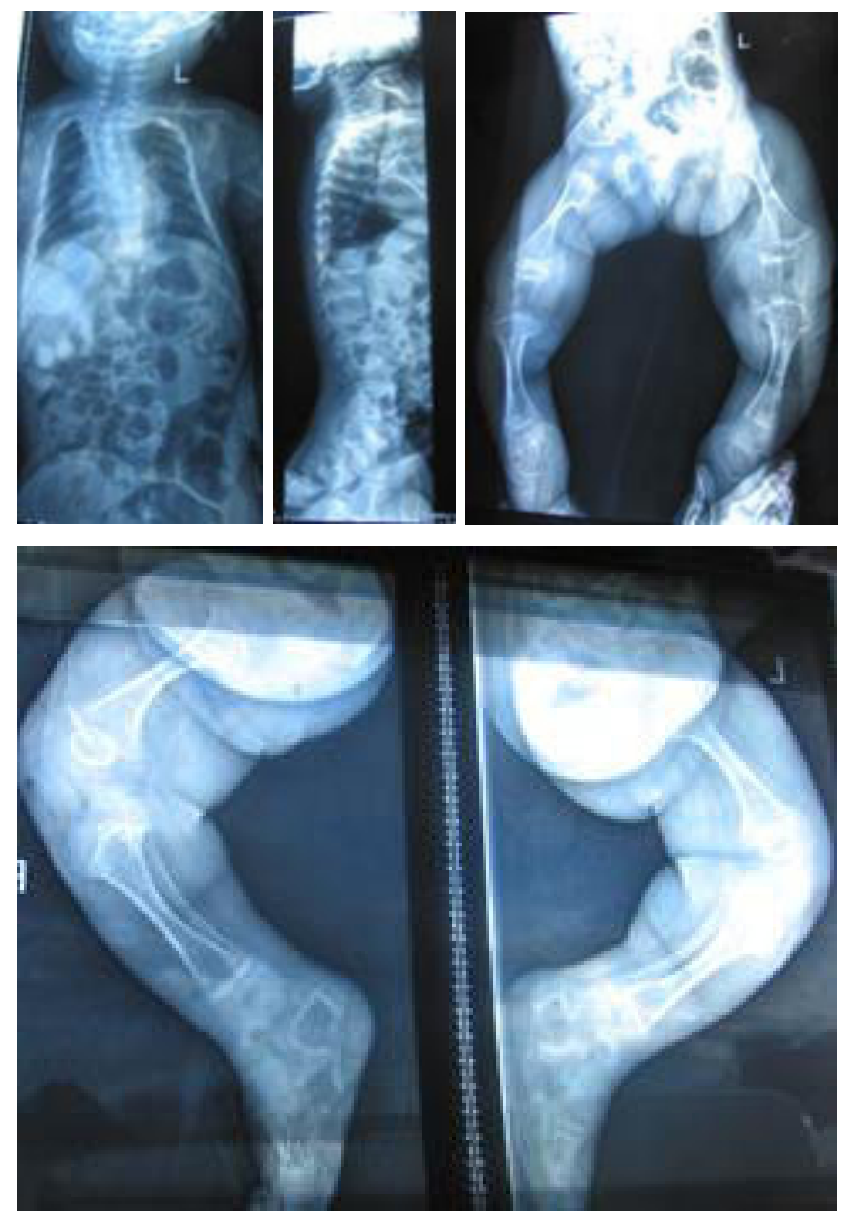

Fig. 2. Radiograph of the MTD affected child

Metatropic dysplasia patient and her parents were sent for molecular genetic screening of mutations in the TRPV4 gene. We performed whole gene sequencing using primers flanking the open reading frame of the gene. It revealed a heterozygous non synonymous substitution c.245C $>\mathrm{T}$ (Fig. 3). At the protein level, the mutation leads to the amino acid substitution p.Pro82Leu in a very conservative position. This mutation was not previously reported, and was not detected in neither of the patient's parents. The predicted functional effect of the missense variant was determined by PolyPhen as probably damaging with a score of 0.989 Also the mutation c. $245 \mathrm{C}>\mathrm{T}$ was not detected among 100 chromosomes in 50 healthy Circassians.

Conclusions. Here we describe the first case of MTD in Russia with confirmed by molecular genetic

\section{References}

1. Kang S. S., Shin S. H., Auh C. K., Chun J. Human skeletal dysplasia caused by a constitutive activated transient receptor potential vanilloid 4 (TRPV4) cation channel mutation. Exp. Mol. Med. 2012;44(12):707-722.

2. Kannu P., Aftimos S., Mayne V., Donnan L., Savarirayan $R$. Metatropic dysplasia: clinical and radiologic findings in 11 patients demonstrating long-term natural history. Am. J. Med. Genet. 2007;143A: 2512-2522.

3. Krakow D., Vriens J., Camacho N., Luong P., Deixler H. et al. Mutations in the gene encoding the calcium-permeable ion channel TRPV4 produce spondylometaphyseal dysplasia, Kozlowski type and metatropic dysplasia. Am. J. Hum. Genet. 2009;84:307-315.

4. Nishimura G., Lausch E., Savarirayan R., Shiba M., Spranger J. et al. TRPV4-associated skeletal dyspla- methods diagnosis. A novel de novo heterozygous missense mutation c.245C $>T$ in TRPV4 gene has been revealed. These findings exclude autosomal recessive inheritance, and support the hypothesis of an autosomal dominant inheritance of MTD in the reported case with defined de novo missense mutation c. $245 \mathrm{C}>\mathrm{T}$ in TRPV4 gene. According to OMIM the probability of re-birth of the sick child in families with MTD is 1:20 because of gonadal mosaicism. So gonadal mosaicism should be suspected in each case de novo mutations in the TRPV4 gene. For the prevention of re-birth of children with MTD prenatal diagnosis in the next possible pregnancies in such families is recommended.


Fig. 3. Chromatograms of TRPV4 sequencing of the proband with c. $245 \mathrm{C}>\mathrm{T}$ mutation (1), her healthy father (2)

and mother (3). The arrow indicates the c.245 nucleotide

Based on the OMIM data on reported families with healthy parents the ratio of MTD affected to unaffected sibs are close to 1:20, which is much higher than population incidence. So the gonadal mosaicism of the causative mutation should be suspected in each de novo MTD case [6]. For this reason the prenatal screening for the revealed mutation is recommended to the family for next pregnancies.

Acknowledgements. This work was supported by the Russian Foundation for Basic Research under grant number 14-04-00525 and 15-04-01859.

sias. Am. J. Med. Genet. C. Semin. Med. Genet. 2012;160C(3): 190-204.

5. Orphanet Reports Series. Available at http:// www.orpha.net/consor/cgi-bin/Disease_Search. php? Ing=EN\&data_id=546\&Disease_Disease_Search diseaseGroup=Metatropic-dysplasia. Date of last application 5.04.2016.

6. Online Mendelian inheritance in man. Available at http:// omim.org/entry/156530\#11. Date of last application 5.04.2016.

7. Tae-Joon C., Kazu M., Dai J., Cho T. J., Matsumoto K. et al. TRPV4-pathy manifesting both skeletal dysplasia and peripheral neuropathy: a report of three patients. Am. J. Med. Genet. 2012;158A(4):795-802. 


\title{
About authors:
}

Timkovskaya Elizabeth, PhD, Senior Researcher, Laboratory of Genetic Epidemiology; tel.: +7(499)3206090; e-mail: timkovskaja@rambler.ru

Makaov Amin, MD, chief physician; tel.: +7(87873)51161; e-mail: makaov@yandex.ru

Mikhailova Lyudmila, MD, PhD, Professor, Central Research Institute of Traumatology and Orthopedics N.N. Priorova; tel.: +7(495)4504511; e-mail: cito-uchsovet@mail.ru

Kutsev Sergey, MD, PhD, Director of Research Centre for Medical Genetics;

Head of the Department of Molecular and Cellular Genetics, Pirogov Russian National Research Medical University; tel.: +7(499)6128607; e-mail: kutsev@mail.ru

Zinchenko Rena, MD, PhD, Professor, Deputy Director for Science, Head of the Laboratory of Genetic Epidemiology; tel.: +7(499)3241224; e-mail: renazinchenko@mail.ru

\section{LEVELS OF NEUROTROPIC AUTOANTIBODIES IN PATIENTS WITH SCHIZOPHRENIA}

Baturin V. A. ${ }^{1}$, Baturina M. V. ${ }^{1,2}$, Mamtseva G. I. ${ }^{3}$, Boev O. I. ${ }^{1,4}$, Yarovitsky V. B. ${ }^{1,4}$, Grudina E. V. ${ }^{2}$

1 Stavropol State Medical University, Russian Federation

${ }^{2}$ Center for Clinical Pharmacology \& Pharmacotherapy, Stavropol, Russian Federation

${ }^{3}$ Research Company IMMUNOTEX, Stavropol, Russian Federation

${ }^{4}$ Regional Clinical Psychiatric Hospital 1, Stavropol, Russian Federation

\section{ИЗУЧЕНИЕ УРОВНЕЙ НЕЙРОТРОПНЫХ АУТОАНТИТЕА У БОАЬНЫХ ШИЗОФРЕНИЕЙ}

\author{
В. А. Батурин ${ }^{1}$, М. В. Батурина', 2, Г. И. Мамцева ${ }^{3}$, О. И. Боев ${ }^{1,4}$, В. Б. Яровицкий1, , \\ Е. В. ГруАина ${ }^{2}$
}

${ }^{1}$ Ставропольский госуАарственный меАицинский университет, Российская ФеАерация

2 Центр кАинической фармакологии и фармакотерапии, Ставрополь, Российская Фелерация

3 Иммунотэкс, Ставрополь, Российская Фелерация

${ }^{4}$ Краевая кАиническая психиатрическая больница № 1, Ставрополь, Российская Фелерация

\footnotetext{
Plasma levels of IgG autoantibodies to the NMDA-receptors, human S-100 protein, and dopamine Type 2 receptors were detected in 26 males suffering from schizophrenia. Half of the patients had their levels of autoantibodies to the NMDA-receptors above average values, while in the rest of the group the antibody level was within norm. Following that, the patients were divided into two groups: Group 1 with a higher level of antibodies to the NMDA-receptors, Group 2 - with their normal levels of antibodies to the NMDA-receptor. The patients in the Group 1 also revealed significantly elevated levels of autoantibodies to the dopamine Type 2 receptors as well as to the S-100 protein in their blood plasma. Psychometric testing involving the PANSS scale showed that the positive symptoms' values in the Group 1 were below those in the Group 2 while the negative symptoms' values in the Group 1 were higher. Respectively, the composite index, which is determined as the difference between the positive and the negative scores, was lower in the Group 1 and higher in the Group 2.
}

Key words: schizophrenia, autoantibodies, NMDA-receptors, dopamine receptors, S-100 protein

Определяли содержание в плазме крови IgG аутоантител к NMDA-рецепторам, к белку S-100 человека и к дофаминовым рецепторам 2 типа у 26 мужчин, больных шизофренией. Уровень аутоантител к NMDAрецепторам был выше нормальных значений у половины больных, у остальных - содержание антител было 